\title{
Corrigendum: Genomic Assays in Node Positive Breast Cancer Patients: A Review
}

\author{
Maroun Bou Zerdan ${ }^{1 \dagger}$, Maryam Ibrahim ${ }^{2 \dagger}$, Clara El Nakib ${ }^{1}$, Rayan Hajjar ${ }^{1}$ \\ and Hazem I. Assi ${ }^{1 *}$ \\ ${ }^{1}$ Department of Internal Medicine, Naef K. Basile Cancer Institute, American University of Beirut Medical Center, Beirut, Lebanon, \\ 2 Division of Internal Medicine, Massachusetts General Hospital and Harvard Medical School, Boston, MA, United States
}

Keywords: breast cancer, oncotype Dx, MammaPrint, PAM50, endopredict, breast cancer index, genomic grade index, immunohistochemistry

\section{A Corrigendum on}

Genomic Assays in Node Positive Breast Cancer Patients: A Review By Bou Zerdan M, Ibrahim M, Nakib CE, Hajjar R and Assi HI. (2021). Front. Oncol. 10:609100. doi: 10.3389/fonc. 2020.609100

In the original article, there was an error. MINDACT trial is misspelled as MINDCAT on three occasions.

A correction has been made to Discussion, MammaPrint and BluePrint, MammaPrint, Role in Node Positive Disease, paragraph 2:

"Here it is important to mention that panellists from BCTEG compared suggestions from the Early Breast Cancer Trialist's Collaborative Group (EBCTCG) to the suggestions that a 10-year follow-up for the MINDACT is needed."

A correction has been made to Discussion, MammaPrint and BluePrint, BluePrint, Validation

Approved by:

Frontiers Editorial Office, Frontiers

Media SA, Switzerland

${ }^{*}$ Correspondence:

Hazem I. Assi

ha157@aub.edu.lb

${ }^{\dagger}$ These authors share first authorship

Specialty section: This article was submitted to Breast Cancer,

a section of the journa

Frontiers in Oncology

Received: 26 March 2021 Accepted: 29 March 2021

Published: 14 April 2021

Citation:

Bou Zerdan M, Ibrahim M, El Nakib C, Hajjar R and Assi HI (2021) Corrigendum: Genomic Assays in Node Positive Breast

Cancer Patients: A Review.

Front. Oncol. 11:686355. doi: 10.3389/fonc.2021.686355
Studies, paragraph 4.

"In a study done by Viale et al. using the same patient population enrolled in the previously mentioned MINDACT trial, IHC/FISH was compared to both Amsterdam 80-gene and Amsterdam 70-gene (83)."

In the original article, there was a mistake in Table 2 as published. The MINDACT trial is misspelled as MINDCAT. The corrected Table $\mathbf{2}$ appears below:

In the original there was another error. The following are the latest NCCN guidelines for different genomic assays when it comes to node +ve diseases. First, NCCN considers all gene expression assays in node +ve disease as prognostic, but it is yet unknown if these assays are predictive in patients with 1-3 +ve LNs. All gene expression assays have a level IIA NCCN category of evidence and consensus except for PAM 50, which has an evidence level of category I. PAM50 should be MammaPrint. MammaPrint is the only test with level I evidence for $\mathrm{LN}+$ patients. The correction has been made to Concluding Recommendations:

"All gene expression assays have a level IIA NCCN category of evidence and consensus except for Mammaprint, which has an evidence level of category I."

In the original article the author's citation for Clara El Nakib was incorrect. The correct citation is "El Nakib C".

The authors apologize for these errors and state that these do not change the scientific conclusions of the article in any way. The original article has been updated.

Copyright $\odot 2021$ Bou Zerdan, Ibrahim, El Nakib, Hajjar and Assi. This is an open-access article distributed under the terms of the Creative Commons Attribution License (CC BY). The use, distribution or reproduction in other forums is permitted, provided the original author(s) and the copyright owner(s) are credited and that the original publication in this journal is cited, in accordance with accepted academic practice. No use, distribution or reproduction is permitted which does not comply with these terms. 
TABLE 2 | ASCO, American Society of Clinical Oncology; EGTM, European Group on Tumor Markers; ER+, Estrogen-receptor-positive; ESMO, European Society for Medical Oncology; NCCN, National Comprehensive Cancer Network; DBCG, Danish Breast Cancer Group; CCTG, Canadian Cancer Trials Group.

\begin{tabular}{|c|c|c|c|c|c|}
\hline & $\begin{array}{c}\text { Oncotype DX } \\
\text { (21-gene assay) }\end{array}$ & $\begin{array}{c}\text { MammaPrint } \\
\text { (70-gene assay) }\end{array}$ & Prosigna(50-gene assay) & $\begin{array}{l}\text { EndoPredict } \\
\text { (12-gene assay) }\end{array}$ & $\begin{array}{l}\text { Breast Cancer } \\
\quad \text { Index } \\
\text { (7-gene assay) }\end{array}$ \\
\hline $\begin{array}{l}\text { Retrospective } \\
\text { Studies }\end{array}$ & $\begin{array}{l}\text { NSABP B-20 (5) SWOG-8814 } \\
\text { (26), (TransATAC (22), } \\
\text { SEER } 18 \text { (145), WSG-ADAPT } \\
\text { (38) }\end{array}$ & $\begin{array}{l}\text { Pooled database of } 7 \\
\text { prospective trials (144) }\end{array}$ & $\begin{array}{l}\text { ATAC (96), ABCSG-8 (98), } \\
\text { DBCG (100) }\end{array}$ & $\begin{array}{l}\text { ABCSG-6 (107), } \\
\text { ABCSG-8 (98) }\end{array}$ & $\begin{array}{l}\text { Stockholm (111), } \\
\text { TransATAC (22), } \\
\text { CCTG, MA.17 (112), } \\
\text { aTTOM trial (120) }\end{array}$ \\
\hline $\begin{array}{l}\text { Prospective } \\
\text { Studies }\end{array}$ & TAILORX, RxPONDER. & MINDACT, PROMIS & OPTIMA & NA & NA \\
\hline $\begin{array}{l}\text { Prognostic/ } \\
\text { Predictive }\end{array}$ & $\begin{array}{l}\text { Yes for both, 10-year RR and } \\
\text { adjuvant chemotherapy } \\
\text { benefit }\end{array}$ & Only Prognostic, 10-year RR & $\begin{array}{l}\text { Yes for both, } 10 \text {-year RR and } \\
\text { late recurrence (>5 years) for } \\
\text { patients HR+ve and LN-ve } \\
\text { disease }\end{array}$ & $\begin{array}{l}\text { Only prognostic, } 10- \\
\text { year RR }\end{array}$ & $\begin{array}{l}\text { Yes for both, } \\
10 \text {-year RR and late } \\
\text { recurrence ( }>5 \text { years) } \\
\text { extended adjuvant } \\
\text { endocrine therapy } \\
\text { benefit }\end{array}$ \\
\hline
\end{tabular}

NCNN* discussed but not specifically recommended. 